\title{
Biodiversity of fungi colonising aboveground parts of zucchini (Cucurbita pepo L. var. giromontina)
}

\author{
Agnieszka Jamiolkowska ${ }^{1}$, Krzysztof Sawicki ${ }^{2}$ \\ ${ }^{1}$ Department of Plant Protection and Quarantine \\ University of Life Sciences in Lublin \\ Leszczyńskiego 7, 20-069 Lublin, Poland \\ ${ }^{2}$ Department of Vegetables and Medicinal Plants \\ University of Life Sciences in Lublin \\ Leszczyńskiego 58, 20-069 Lublin, Poland \\ e-mail: aguto@wp.pl
}

\begin{abstract}
Zucchini is a very valuable vegetable, easy to grow both in the field and under covering, but it is affected by pathogenic fungi. The experiment was carried out at a farm near Lublin where three zucchini cultivars, 'Astra Polka', 'Atena Polka $F_{1}$ ' and 'Soraya', were cultivated in a plastic tunnel and in the field in 2008-2009. The leaves, petioles and stems of zucchini were collected for laboratory tests. Mycological analysis showed that the predominating fungi were Alternaria alternata, Fusarium spp. and Rhizoctonia solani. Fusarium spp. were isolated in the greatest numbers from zucchini plants cultivated in the field. $R$. solani was isolated in greater numbers from zucchini cultivated in a plastic tunnel as compared to the field.
\end{abstract}

Key words: zucchini, Alternaria alternata, Rhizoctonia solani, Fusarium spp.

\section{INTRODUCTION}

Zucchini (Cucurbita pepo L. var. giromontina) is a valuable vegetable from the family Cucurbitaceae. It is dependable in cultivation and is characterised by a high fertility rate. Zucchini grown in the greenhouse and field conditions is usually infected by pathogens specific to the Cucurbitaceae family species, as well as organisms characteristic of other plantations (Sumner et al. 1983, Kimati et al. 1997). These are: Pseudoperonospora cubensis (Berk. Et Curt.), Erysiphe cichoracearum D.c. et Merat, Alternaria alternata Keiss., Botrytis cinerea Pers., Fusarium spp., Rhizoctonia solani Kühn, and Sclerotinia sclerotiorum (Lib.) de Bary (Hikal 2007). A. alternata is important for the health of zucchini cultivated in the field. That fungus causes necrotic spots on the leaves (Mesbah et al. 2000). Its destructive effect towards the host plant is a result of enzyme and toxin production (Rotem 1994). An important pathogen causing pre- and post-harvest diseases in vegetables is $B$. cinerea (Wagner 2004, Jamiołkowska 2009a). Similarly, $R$. solani is a fungal pathogen causing damping-off on several horticultural crops with consistent loss of production under both greenhouse and open field conditions (Sumner et al. 1983, 1995).

The aim of the study was to investigate the occurrence and diversity of fungi colonising the aboveground part of zucchini plants grown in plastic tunnels and in the field.

\section{MATERIAL AND METHODS}

The experiments were conducted in 2008 and 2009 in Łuszczów near Lublin (Lubelskie province) on an independent horticultural farm. The objects of study were three zucchini plant cultivars (Cucurbita 
pepo L. var. giromontina): 'Astra Polka', 'Atena Polka $F_{1}$ ', and 'Soraya'. The zucchini seedlings were produced at the Experimental Station of the University of Life Sciences in Felin. Plants from each cultivar were planted in a plastic tunnel (1st ten days of May) and in the field (2nd ten days of May), at a spacing of $100 \mathrm{~cm}$ in a row and 80 $\mathrm{cm}$ between rows. In the experiment the method of random squares in four replications (40 plants on each combination) was used in the following combinations: 1 - 'Atena Polka' plastic tunnel, 2 - 'Astra Polka F ${ }_{1}$ 'plastic tunnel, 3 - 'Soraya' plastic tunnel, 4 - 'Atena Polka' field, 5 -'Astra Polka F,' field, and 6 - 'Soraya' field. Before setting up the experiment, mineral fertilsation was used according to the recommendations for Cucurbitaceae, after a previous analysis of the soil. During the vegetation season the plants were manually weeded and they were not chemically protected. The observations of plant health status were conducted at the beginning of fructification ( $2^{\text {nd }}$ decade of July), when four plants from each combination were collected for mycological analysis. Four plants were taken for a laboratory analysis at random from each experimental combination. Stems, petioles and leaves of zucchini from each experimental combination were analysed in the laboratory according to the method described by Jamiołkowska
(2007). For each experimental treatment, 20 dishes with the plant material (10 dishes - stems, 10 dishes - petioles and leaves), 10 plant fragments per dish, were prepared and incubated at $20-22^{\circ} \mathrm{C}$ for seven days in the dark. The obtained colonies of fungi were transferred to a potato-dextrose medium (PDA-Difco) and the species were identified with the available monographs.

The fungal communities were compared according to the numerical classification method using the statistical program SYN-TAX 5.01. In this study the analysis of the communities' similarity was carried out based on similarity coefficients, i.e. percentage differences shown on the axis on a $0-1$ scale. In this case, 0.1 per cent difference between communities corresponded to a $90 \%$ similarity of these communities (Podani 1993). Analysing the data describing the communities studied using the SYN-TAX program, a dendrogram showing relations between the compared communities was obtained.

\section{RESULTS AND DISCUSSION}

Rot on the stems, necrotic spots on leaves and leaf petioles were found during field observations (Phots 1, 2, 3). A mycological analysis of the leaves and stems provided 1985 isolates of fungi representing 20 species (1065 from leaves and petioles, 920 from

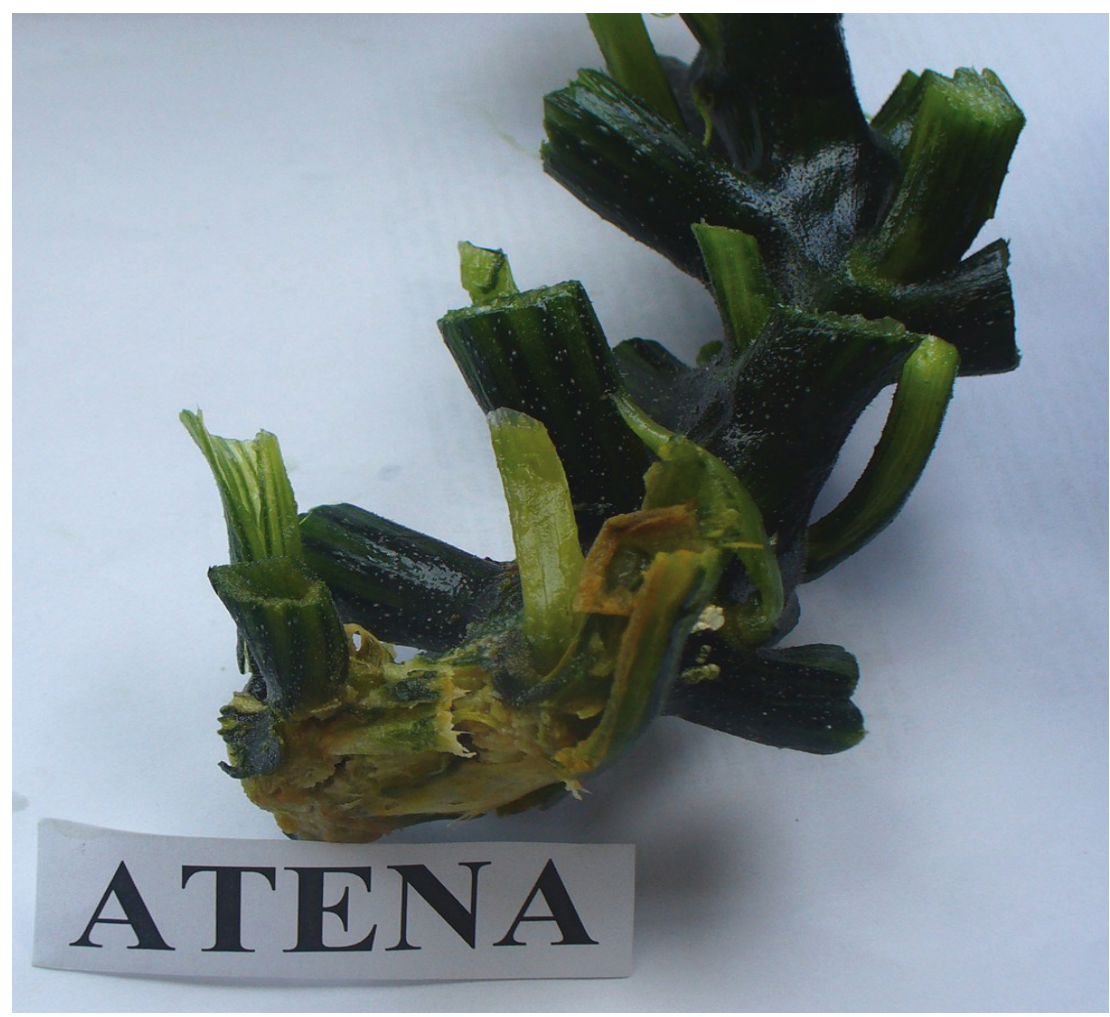

Photo 1. Rot of the stem of zucchini (photo by A. Jamiołkowska) 


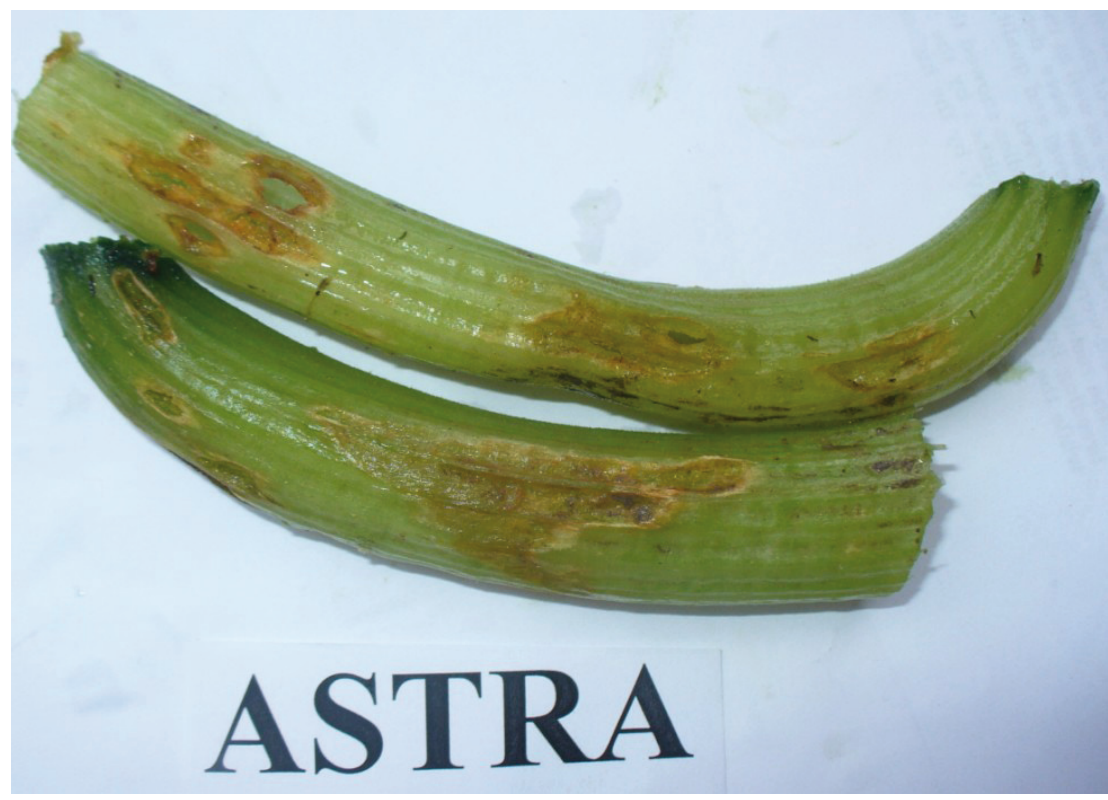

Photo 2. Necrotic spots on the petioles of zucchini plants (photo by A. Jamiołkowska)

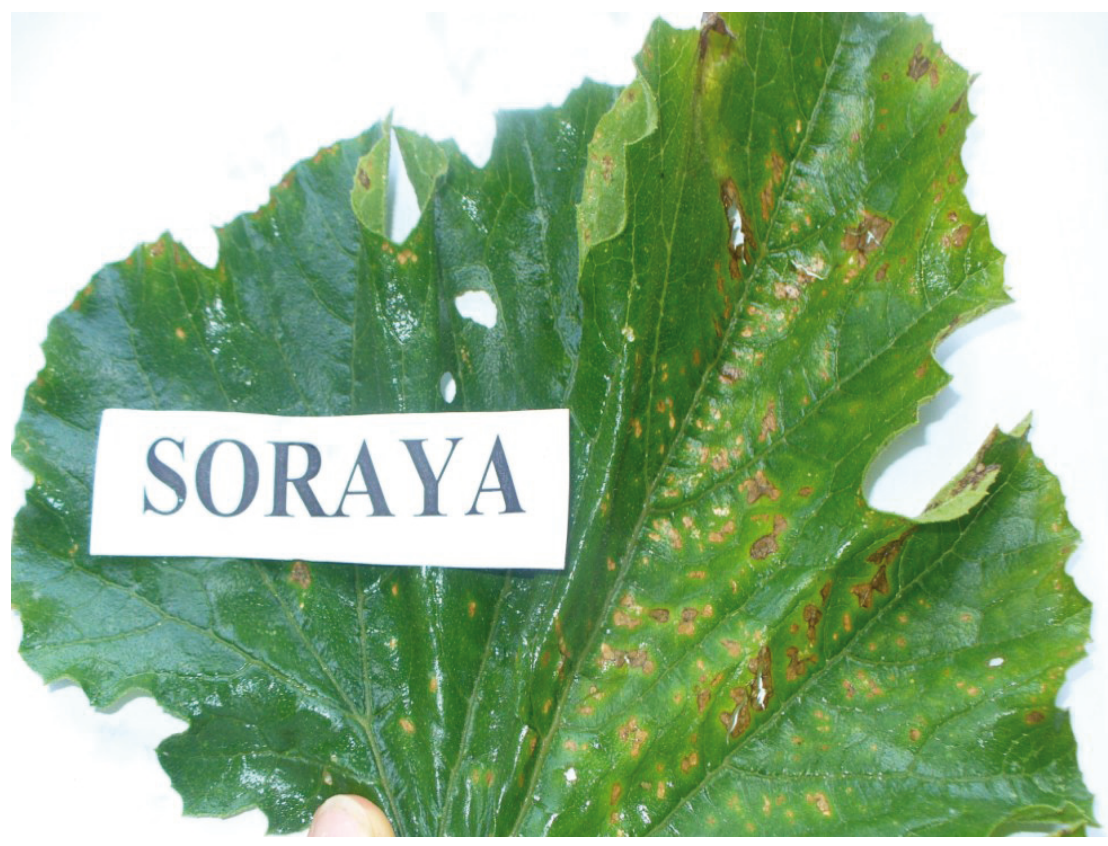

Photo 3. Necrotic spots on the leaf of zucchini (photo by A. Jamiołkowska)

stems) (Tabs 1, 2). Besides fungi, numerous bacteria were also observed on the medium. The dominating fungi species were A. alternata, $R$. solani, $M$. hiemalis $(22.5 \%, 23.2 \%$, and $28.6 \%$ of the total number of fungi, respectively). More isolates of fungi were obtained in 2009 than in 2008, as well as from the plants cultivated in the field as compared to the cultivation in a plastic tunnel.

A. alternata was the dominant of the aboveground part. It is a polyphagous species that, causes irregular, necrotic spots covering a considerable part of the plant in plants whose condition has worsened (Wagner 2004, Jamiołkowska 2009a).
This species - called a "pathogen weakness" - can colonise the plants' aboveground parts without any symptoms. During the infection process it produces toxins that have a destructive effect on the host plant (Rotem 1994, Robiglio and Lopez 1995). A. alternata can be dangerous to zucchini not only by causing a decrease in photosynthesis, but also by causing a drop in the commercial yield of the fruit (Jamiołkowska and Buczkowska 2009). R. solani was another species that occurred in large numbers on the aboveground part of zucchini (Tabs 1, 2). It was isolated in large numbers from the leaf petioles of zucchini grown in a plastic tunnel as well as 


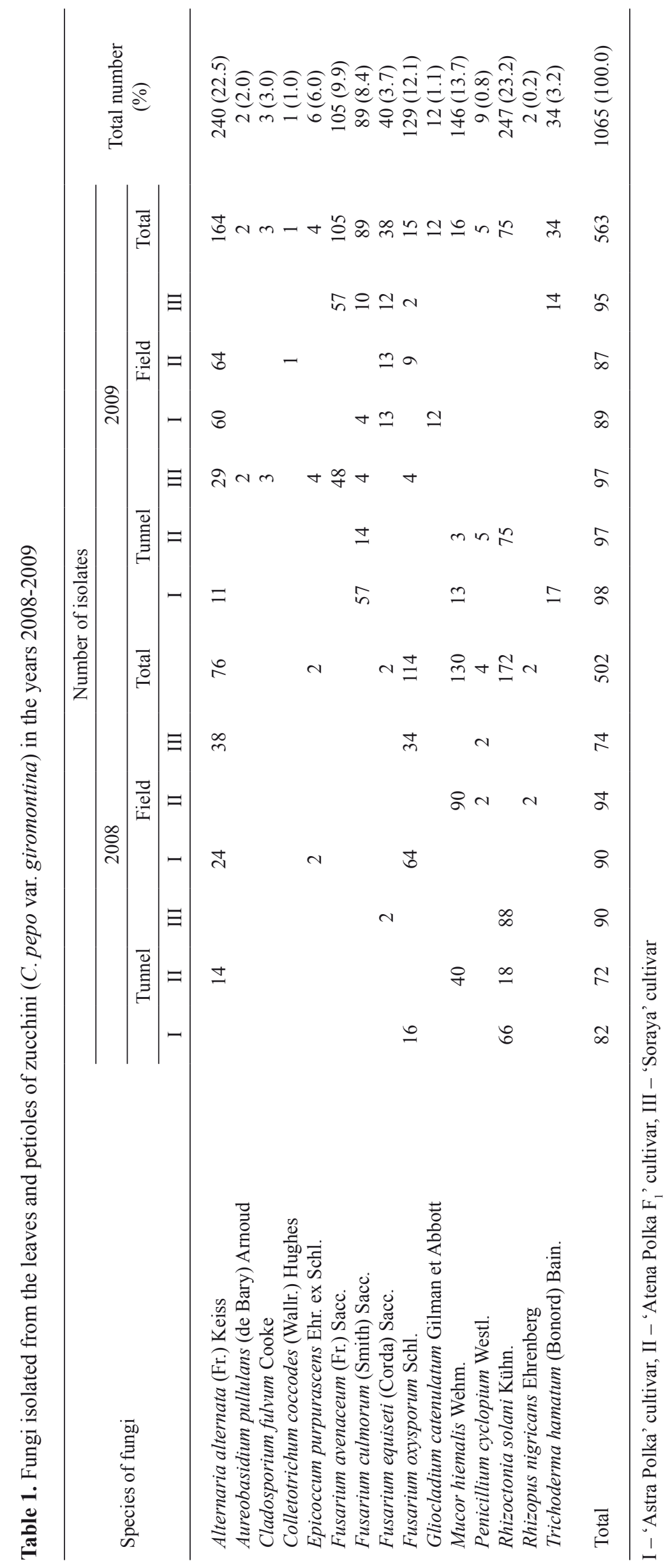




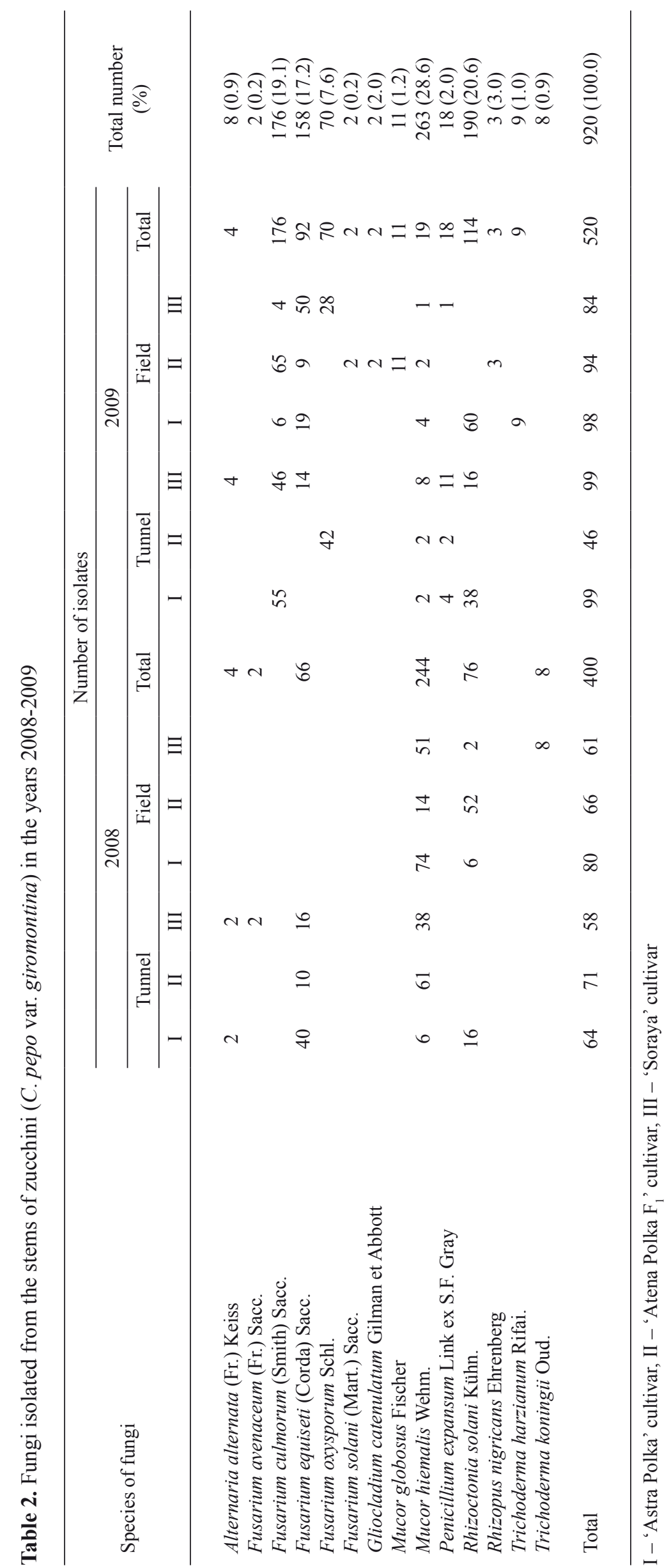




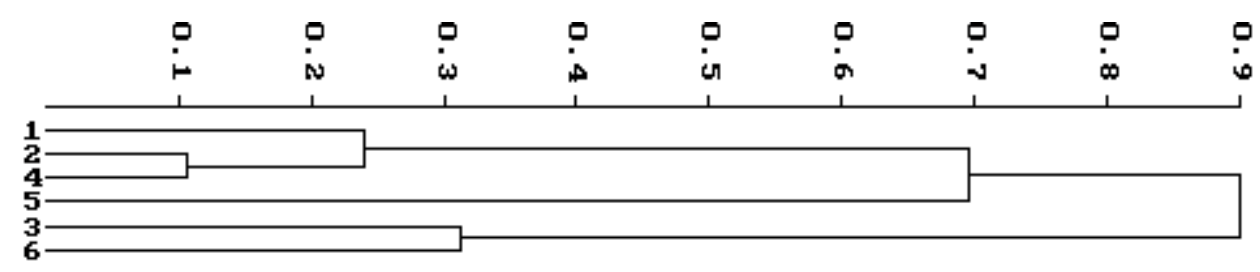

Figure 1. Dendrogram showing the classification of fungal communities from the tested cultivars of the aboveground parts of zucchini plants cultivated in a plastic tunnel and in the field in 2008-2009; 1 - 'Atena Polka' plastic tunnel, 2 - 'Astra Polka F', plastic tunnel, 3 - 'Soraya' plastic tunnel, 4 - 'Atena Polka' field, 5 -'Astra Polka F ' field, 6 - 'Soraya' field

from zucchini cultivated in the field. $R$. solani is considered to be one of the factors causing the rot of seedlings of many cultivated plants (Kućmierz and Kaczyńska 2005, Kućmierz and Kuc 2006, Kućmierz and Syta 2008). The studies showed that it can also cause the rot of the stems and leaf petioles of zucchini in the period of its fructification.

Fusarium spp. are important in the pathogenesis of several vegetable plants (Jamiołkowska and Wagner 2005, Jamiołkowska 2009b, and Jamiołkowska and Buczkowska 2009). It occurred in greater numbers in 2009 as compared to 2008 and on zucchini cultivated in the field as compared to plastic tunnels. The frequencies of Fusarium spp. were the highest in the 'Soraya' cultivar. F. culmorum (19.1\% of the fungi obtained from the stems) and $F$. avenaceum $(9.9 \%$ of fungi from the leaves and petioles) dominated on the aboveground part (Tabs 1, 2). Several researchers (Machowicz-Stefaniak et al. 2002, Zalewska and Machowicz-Stefaniak 2004, Jamiołkowska and Wagner 2005) reported strong pathogenic properties of $F$. culmorum and $F$. avenaceum towards the seedlings of pepper and some spice plants. They caused an inhibition of the emergence and growth of pepper, lemon balm and common thyme seedlings. $F$. culmorum is known for producing deoxynivalenol, which is not only responsible for the development of tissue necrosis, but is also harmful to human beings (Wojciechowski et al. 1996, Hestbjerg et al. 2002). $F$. avenaceum produces antibiotic $\mathrm{Y}$, aurofusarin, butenolide, chlamydosporols, chrysogine, fusarin $\mathrm{C}$, moniliformin (MON), enniatins (ENNs) and beauvericin (BEA), and it can cause the dying out of the seedlings and necrotic lesions on the leaves (Hershenhorn et al. 1992). The harmfulness of Fusarium spp., irrespective of the species and place of their origin, results from the polyphagous character of the parasitism of these fungi (Hershenhorn et al. 1992, Zalewska and Machowicz-Stefaniak 2004).
The analysis of fungal communities performed by a means of numerical classification using the SYN-TAX software allowed for the determination of the similarity level between the studied communities. Fungal communities isolated from the aboveground parts of 'Astra Polka' in plastic tunnel and 'Atena Polka $\mathrm{F}_{1}$ ' cultivated in field (similarity 90\%) and 'Soraya' from a plastic tunnel and field (similarity 68\%) were the most similar (Fig. 1). Therefore, it can be assumed that the population and kind of fungi colonising zucchini cultivars did not depend on the cultivar but on the conditions of its cultivation.

\section{CONCLUSIONS}

1. Alternaria alternata and Rhizoctonia solani were the most numerous on the leaves and leaf petioles of zucchini.

2. The fungi most frequently isolated from zucchini stems were Fusarium spp. and R. solani.

3. Fusarium spp. were isolated in greater numbers from zucchini plants cultivated in the field as compared to those from a plastic tunnel.

4. $R$. solani were isolated in greater numbers from zucchini cultivated in a plastic tunnel as compared to the field.

\section{REFERENCES}

Hershenhorn J., Park S.H., Stierle A., Strobel G.A., 1992. Fusarium avenaceum as a novel pathogen of spotted knapweed and its phytotoxin, acetamidobutenolide and enniatin B. Plant Sci. 86: 155-160.

Hestbjerg H., Nielsen K.F., Thrane U., Elmholt S., 2002. Production of trichothecenes and other secondary metabolites by Fusarium culmorum and Fusarium equiseti on common laboratory media and soil organic matter agar: an ecological interpretation. J. Agric. Food Chem. 50(26): 7593-7599.

Hikal N.Z., 2007. Improving biological control of Fusarium root-rot in cucumber (Cucumis sativus L.) by allelopathic plant extracts. Int. J. Agri. Biol. 9(3): 459-461. 
JAMioŁKowska A., Wagner A., 2005. Fungal communities from the rizosphere of tomato cultivated conventionally and with rye as cover crop. EJPAU, 8(4), (http://www.ejpau.media.pl/volume8/issue4/art04.html).

JAMioŁKowska A., 2007. Effect of field pea (Pisum arvense L.) as cover plant on health of under-ground part of field tomato. Veg. Crops Res. Bull. 67: 71-79.

JAMiOŁKowsKa A., 2009a. Fungi colonizing stems and leaves of hot pepper plants (Capsicum annuum L.) cultivated in field. EJPAU, 12(2). (http.//www.ejpau. media.pl/volume12/issue2/art-07.html)

JAMIOŁKOWSKA A., 2009b. Fungi isolated from underground part of hot pepper (Capsicum annuum) plants cultivated in the field. Phytopathol. Pol. 51: 37-44.

JamioŁkowska A., Buczkowska H., 2009. Grzyby występujące na papryce słodkiej (Capsicum annuum L.) w uprawie polowej. Progr. Plant Prot./Post. Ochr. Roślin 49(1): 201-208.

Kimati H., Gimenes-Fernandes N., Soave J., Kurozawa C., Brignani Neto F., Bettiol W., 1997. Guia de fungicidas agrícolas: recomendações por cultura. Grupo Paulista de Fitopatologia, Jaboticabal.

KuĆMIERZ J., KaCZyŃSKa A., 2005. Fungi isolated from Dianthus chinensis L. seeds, their pathogenicity to seedlings and attempts at their control. Acta Sci. Pol., Hortorum Cultus 4(2): 39-44.

Kućmierz J., Kuc M., 2006. Grzyby izolowane z nasion goździka chińskiego (Dianthus chinensis) oraz ich patogeniczność dla siewek i próby zwalczania. Prog. Plant Prot./Post. Ochr. Roślin 46(2): 548-551.

Kućmierz J., Syta Ł., 2008. Grzyby izolowane z nasion kukurydzy cukrowej (Zea mays var. saccharata) oraz patogeniczność wybranych gatunków dla siewek i próby ich zwalczania. Progr. Plant Prot./Post. Ochr. Roślin 48(2): 472-476.

Machowicz-Stefaniak Z., Zimowska B., Zalewska E., 2002. Grzyby zasiedlające różne organy tymianku właściwego (Thymus vulgaris L.) uprawianego na Lubelszczyźnie. Acta Agrobot. 55(1): 185-197.

Mesbah L.A., Van Der Weerden G.M., NiJkamp H.J.J., Hille J., 2000. Sensitivity among species of Solanaceae to AAL toxins produced by Alternaria alternata f. sp. lycopersici. Plant Pathol. 49(6): 734-741.

Podani J., 1993. SYN-TAX - pc. Computer Programs for Multivariate Data Analysis in Ecology and Systematics. User's Guide. Scienta Publishing, Budapeszt.

Robiglio A.L., Lopez S.E., 1995. Mycotoxin production by Alternaria alternata strains isolated from red delicious appless in Argentyna. Food Microbiol. 24: 413-417.

Rotem J., 1994. The genus Alternaria: biology, epidemiology and pathogenicity. APS Press, St. Paul.

Sumner D.R., Dowler C.C., Johnson A.W., Glaze N.C., Phatak S.C. Chalfant R.B., Epperson J.E., 1983. Root diseases of cucumber in irrigated, multiplecropping system with pest management Plant Dis. 67: 1071-1075.

Sumner D.R., Phatak S.C., Gay J.D., Chalfant R.B., BRunson K.E., Bugg R.L., 1995. Soilborne pathogens in vegetable double-crop with conservation tillage following winter cover crops. Crop Prot. 14(6): 495-450.

Wagner A., 2004. Fungal communities colonizing stems of hot pepper (Capsicum annuum). Phytopathol. Pol. 33: 23-29.

Wojciechowski S., Wiśniewska H., CheŁkowski J., 1996. Influence of Fusarium culmorum infection and its metabolite deoxynivalenol on membranes stability in barley seedlings. Acta Physiol. Plant. 18(1): 3-6.

Zalewska E., Machowicz-Stefaniak Z., 2004. Patogeniczność grzybów z rodzaju Fusarium dla melisy lekarskiej (Melissa officinalis L.). Acta Sci. Pol., Hortorum Cultus 3(2): 33-39.

\section{BIORÓŻNORODNOŚĆ GRZYBÓW ZASIEDLAJĄCYCH CZESŚĆ NADZIEMNĄ CUKINII (CUCURBITA PEPO L. VAR. GIROMONTINA)}

Streszczenie: Cukinia jest bardzo cennym warzywem, łatwym w uprawie zarówno w polu, jak i pod osłonami. Porażana jest jednak przez różne grzyby patogeniczne. Badania prowadzone były w latach 2008-2009 w gospodarstwie ogrodniczym w okolicach Lublina. Trzy odmiany cukinii 'Astra Polka', 'Atena Polka F', i 'Soraya' wysadzano w polu i tunelu foliowym. Analizie laboratoryjnej poddano liście wraz z ogonkami liściowymi oraz łodygi. Analiza mikologiczna wykazała, że grzybami najliczniej zasiedlającymi część nadziemną cukinii były Alternaria alternata, Fusarium spp. i Rhizoctonia solani. Fusarium spp. był izolowany liczniej z roślin uprawianych w polu, a $R$. solani $\mathrm{z}$ roślin uprawianych w tunelu foliowym.

Received January 4, 2011; accepted October 10, 2011 